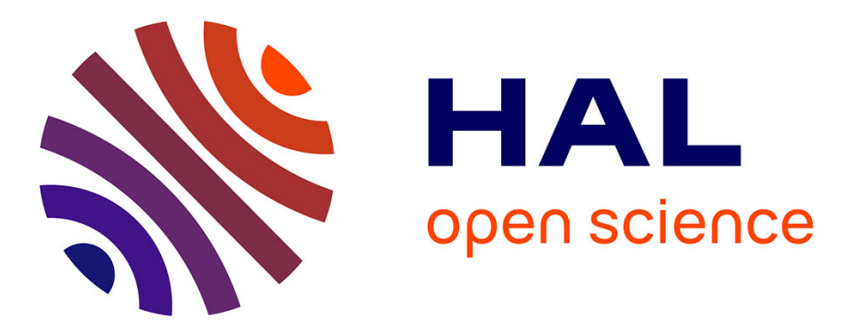

\title{
When are extreme ratings more helpful? Empirical evidence on the moderating effects of review characteristics and product type
}

\author{
Raffaele Filieri, Elisabetta Raguseo, Claudio Vitari
}

\section{To cite this version:}

Raffaele Filieri, Elisabetta Raguseo, Claudio Vitari. When are extreme ratings more helpful? Empirical evidence on the moderating effects of review characteristics and product type. Computers in Human Behavior, 2018, 88, pp.134 - 142. 10.1016/j.chb.2018.05.042 . halshs-01923243

\section{HAL Id: halshs-01923243 \\ https://shs.hal.science/halshs-01923243}

Submitted on 17 Nov 2018

HAL is a multi-disciplinary open access archive for the deposit and dissemination of scientific research documents, whether they are published or not. The documents may come from teaching and research institutions in France or abroad, or from public or private research centers.
L'archive ouverte pluridisciplinaire HAL, est destinée au dépôt et à la diffusion de documents scientifiques de niveau recherche, publiés ou non, émanant des établissements d'enseignement et de recherche français ou étrangers, des laboratoires publics ou privés. 
When are extreme ratings more helpful? Empirical evidence on the moderating effects of review characteristics and product type

Raffaele Filieri, Elisabetta Raguseo, Claudio Vitari

\begin{abstract}
Online customer reviews (OCRs) have become increasingly important in travelers' decisionmaking. However, the proliferation of OCRs requires e-commerce organizations to identify the characteristics of the most helpful reviews to reduce information overload. This study focuses on OCRs of hotels and particularly on the moderating factors in the relationship between extreme ratings and review helpfulness. The study has adopted 11,358 OCRs of 90 French hotels from TripAdvisor.com. Findings highlight that large hotels are more affected by extreme reviews than small hotels. Extreme reviews are more helpful to consumers when reviews are long and accompanied by the reviewers' photos.
\end{abstract}

Keywords: online consumer review helpfulness; extreme rating; review length; hotel photos; hotel size; reviewer's country of origin.

\title{
Introduction
}

Online consumer reviews (OCRs) are a very popular source of information about products and services; $72 \%$ of 25-34 year old American consumers look to social media contacts for recommendations and opinions before purchasing goods and services (Mintel, 2015). OCRs can be defined as any comment on a product, service, brand shared online by a former customer (Filieri, 2016).

OCRs have radically changed the way tourists plan their trips (Litvin, Goldsmith, \& Pan, 2008) and made websites like TripAdvisor.com leading players in the travel and tourism industry. Travelers trust anonymous reviewers more than other sources of information 
(Sparks, Perkins, \& Buckley, 2013) and they gather in online communities for sharing their travel experiences and reviews.

However, the proliferation of OCRs and the wealth of available information generate information overload (Park \& Lee, 2008), which makes it difficult for consumers to orientate and to determine which information is the most helpful for them. The helpfulness of a customer review indicates its diagnosticity, namely its capacity to enable other consumers to better understand the quality and performance of a product or service (Jiang \& Benbasat, 2007). Since helpful OCRs can increase sales (Ghose \& Ipeirotis, 2011), a number of ecommerce and third-party organizations are enabling consumers to vote the helpfulness of each review to signal to other consumers which reviews are most helpful for assessing products’ quality and performance.

Scholars in marketing (e.g. Pan \& Zhang, 2011; Filieri, 2015), information systems (e.g. Mudambi \& Schuff, 2010; Racherla \& Friske, 2012; Korfiatis, García-Bariocanal, \& Sánchez-Alonso, 2012; Yin, Bond, \& Zhang, 2014; Huang et al., 2015; Chua \& Banerjee, 2016), and tourism (e.g. Liu \& Park, 2015; Park \& Nicolau, 2015; Fang et al., 2016) have started to examine what makes an online review helpful.

However, research has found contrasting results regarding the role of extreme review ratings (or review extremity) in predicting review helpfulness (Hong et al., 2017). Mudambi \& Schuff (2010) found that reviews with extreme ratings are less helpful than reviews with moderate ratings for experience goods, while reviews with extreme OCR ratings receive more helpful votes than those with mixed or neutral opinions for different software programs (Cao, Duan, \& Gan, 2011). In the travel and tourism industry scholars found that the restaurant reviews with extreme ratings are voted as helpful by consumers (Park \& Nicolau, 2015), however other studies show that travelers perceive some extreme reviews as untrustworthy, thus unhelpful (Filieri, 2016). 
While the understanding of the factors directly affecting helpfulness is consolidating, the moderating effects are still unexplored (Kwok \& Xie, 2016; Karimi \& Wang, 2017). For instance, Kwok and Xie (2016) found that the response of a hotel manager moderates the influence of reviewer experience on the helpfulness of online reviews, while Karimi and Wang (2017) investigated the moderation of review length, rating valence and equivocality in the relationship between reviewer's profile photo and review helpfulness.

The moderating factors intervening in the relationship between extreme reviews and review helpfulness have not been investigated, and the may help understanding the reason of the contrasting results in literature. We aim to contribute to this research debate by answering the following research question: What are the moderating effects in the relationship between extreme ratings and helpfulness?

Most studies in eWOM recognize the importance of source and message characteristics in the analysis of the factors influencing consumer's decision to vote a review as helpful (e.g. Huang et al., 2015; Kwok \& Xie, 2016; Karimi \& Wang, 2017). Mudambi \& Schuff (2010) revealed that product type moderates the effect of review extremity on the helpfulness of the review. Furthermore, the relationship between information quality and review helpfulness was found to vary as a function of product type in Chua and Banerjee (2016)'s study. These findings imply that the type of product being reviewed is also an important factor to consider when researching the moderators of review helpfulness. Following this literature, we conjecture that factors relating to source of communication, message, and product type, can play the role of moderators. In the tested model, two factors refer to the characteristics of the review message, namely the length of a review and visual information accompanied with the review (i.e. the photos of the hotel posted by the reviewer); one factor refers to the source of communication, namely the local versus foreign origin of the reviewer, while hotel size (large versus small hotel) concerns the type of product being reviewed. To answer our research 
question, we have used 11,358 OCRs of 90 French hotels from TripAdvisor.com and used Tobit regression to test our model.

\section{Literature review}

Research in the travel and tourism industry has shown that OCRs affect hotel sales (e.g. Ye, Law, \& Gu, 2011; Raguseo \& Vitari, 2016), and influence hotels’ revenue growth and profitability, hotels’ preferences (Viglia, Furlan, \& Ladrón-de-Guevara, 2014) and hotel’s performance (Phillips et al., 2015). Scholars have also investigated who uses OCRs and why (Ayeh, Au, \& Law, 2013) and their importance at different stages of the travel planning process (Gretzel et al., 2007; Papathanassis \& Knolle, 2011), as well as the factors influencing purchase intention (Park, Lee, \& Han, 2007; Filieri \& McLeay, 2014; Zhang, Wu, \& Mattila, 2016), the antecedents of trust towards consumer reviews (Cox et al., 2009; Yoo \& Gretzel, 2009; Filieri, 2016), and user-generated media (Filieri, Alguezaui, \& McLeay, 2015) and the effect of hotel manager's response to negative reviews on trust and concern (Sparks, So, \& Bradley, 2016).

The literature on the determinants of review helpfulness for travel and tourism services is rapidly developing. The explored factors so far are: the review characteristics and valence, in terms of content quality, length, complexity, readability, rating and extreme ratings (Liu \& Park, 2015; Park \& Nicolau, 2015; Fang et al., 2016; Kwok \& Xie, 2016), the reviewer background and characteristics, such as the reviewer's expertise, reputation, and identity disclosure (Liu \& Park, 2015; Park \& Nicolau, 2015; Fang et al., 2016), the manager’s reply to a review message (Kwok \& Xie, 2016). For instance, Liu and Park (2015) use 5,090 reviews from Yelp of 35 restaurants in London and of 10 restaurants in New York. They look at the influence of review content quality factors and of reviewer background on review helpfulness. The authors found that the number of friends, Elite awards, and fans (connoting 
the reviewer's reputation), the star rating, the squared star rating and word count had a positive influence on helpful votes (Liu \& Park, 2015). They also found that perceived enjoyment, when added to the equation, highly contributed to explain the dependent variable, while review complexity had no effect on review usefulness. Using the same dataset, Park and Nicolau (2015) found that extreme ratings are voted as more helpful and enjoyable than moderate ratings, giving rise to a U-shaped line. The authors reveal that the most negative reviews (star rating of 1 ) are the most useful, and the most positive review (star rating of 5) had a similar impact to the second-to-last most negative review (star rating of 2). The reviewer's 'real' photo (identity disclosure) as well as his/her expertise (number of reviews written by the reviewer) and word count affected usefulness and enjoyment while reviewers' 'real' name did not. Fang et al. (2016) used OCRs of attractions within a tourism destination (i.e. New Orleans) from TripAdvisor.com, and found that some reviewer characteristics, namely reviewers writing more reviews stressing positive sides (i.e. mean rating higher than mode rating), and some review characteristics, such as review readability and extremity, predicted review helpfulness. Kwok \& Xie (2016) adopted OCRs of hotels in Texas and found that review helpfulness is negatively affected by rating and review length, while manager's response and reviewer experience (reviewer status, years of membership, and number of cities visited) were positively related to review helpfulness. They also found that manager response moderates the influence of reviewer experience on hotel reviews' helpfulness.

\section{Extreme opinions}

We use the term extreme ratings to identify a consumer review that contains an extremely positive or extremely negative evaluation of a service based on the rating score. For instance, 
extreme ratings are expressed on a scale from 1 (terrible) to 5 (excellent) in TripAdvisor.com (Park \& Nicolau, 2015).

Extremely negative rating displays an extreme opinion about a product or service a customer has purchased or experienced. The role and weight of extreme opinions have been studied in impression formation research. Researchers in impression formation suggest that extreme cues are perceived as less ambiguous (Reeder \& Brewer, 1979; Reeder, Henderson, \& Sullivan, 1982) and more diagnostic (Skowronski \& Carlston, 1989) than cues of moderate strength to categorise individuals. Accordingly, individuals tend to focus on extreme values as reference points, as extreme values are often more salient than more moderate values (Kahneman, 1992). Skowronski \& Carlston (1987) demonstrated that extreme behaviors relating to both ability and morality are perceived as being more diagnostic than moderate behaviors.

A cue that suggests one category is said to be diagnostic as they suggest one categorization over alternative categorizations (Skowronski \& Carlston, 1989). Extreme cues are perceived to be more diagnostic when they lead to higher perceived probabilities that a person belongs to one category and to lower perceived probabilities that the person belongs to alternative categories.

In the case of online ratings of hotels, a hotel that receives a five star rating is more likely to be perceived as an excellent, high quality hotel whereas a hotel that receives a one star rating is more likely to be perceived as belonging to the category of low quality hotels. Extreme cues, such as one and five star ratings, increase consumer's confidence in assigning a product or a service to one category (e.g. poorly or high performing services) and in excluding that product from alternative categories.

Based on the weighted average model (Anderson, 1981), diagnostic cues such as five star and one star ratings in reviews should be weighted more than other ratings as they are more 
diagnostic and less ambiguous and this have a higher impact on impression formation (Birnbaum, 1972; Wyer, 1974; Wyer \& Hinkle, 1976).

Existing research on eWOM in the travel and tourism sector has demonstrated that extreme ratings are more likely to be voted as helpful by users (Park \& Nicolau, 2015; Liu \& Park, 2015; Fang et al., 2016). Following this literature, we hypothesize that:

H1: Reviews with extreme ratings will be more likely to be voted as helpful than reviews with moderate ratings.

\section{Moderators}

If the literature on the determinants on review helpfulness is rapidly developing, the one on the moderating effects intervening in the relationship between review extremity and review helpfulness is in its infancy (Kwok \& Xie, 2016). In the present study we include review message characteristics, namely the length of a review and visual information accompanied with the review (i.e. the photos of the hotel posted by the reviewer); source of communication characteristics, namely the local versus foreign origin of the reviewer; and product type namely large versus small hotels. Our contribution is to hypothesize them as moderators in the relationship between extreme ratings and review helpfulness. Below we discuss the arguments leading to the hypotheses of this study.

\section{Review length}

Scholars proved that the length of the review message has a positive impact on review helpfulness (e.g. Mudambi \& Schuff, 2010; Pan \& Zhang, 2011; Liu \& Park, 2015). Long reviews may contain more information (Pan \& Zhang, 2011) and more convincing arguments (De Ascaniis \& Morasso, 2011) than short reviews. Extensive and well-argued reviews are 
expected to provide sufficient amount of information for a consumer to evaluate the quality of the reviewed product (De Ascaniis \& Morasso, 2011). Moreover, longer reviews are not only perceived as more helpful to assess products' quality but they are also perceived as more trustworthy than short reviews (Filieri, 2016). Indeed, the length of a review approximates how involved the reviewer is in writing a review; thus consumers may find more credible a reviewer who has spent more time in writing a long review than a reviewer who has written only a couple of lines about a hotel (Pan \& Zhang, 2011).

However, less research has been conducted on the moderation effect of review length in the relationship between extreme ratings and review helpfulness. The length of a review could be particularly relevant in the case of hotels. In fact, a hotel is more multifaceted than other services like restaurants, which means that consumers often assess various features (e.g. location, cleanliness, service quality, breakfast, and the like) before making a purchase decision. Because hotels have several important features to assess, a reviewer may write a longer review to persuade the audience that his/her extreme evaluation is accurate. Accordingly, the length of the review may add rationality to the review and justifies the reviewer's extremely positive or extremely negative evaluation. In such a context, we expect that review length moderates the relationship between extreme ratings and review helpfulness.

H2: Review length moderates the relationship between extreme rating and review helpfulness in such a way that extreme review rating will be voted as more helpful when the review is long.

Reviewer's photo of the hotel 
According to Nisbett and Ross (1980) vivid information, including photos, is more likely to engage people in cognitive elaboration, compared to the same information presented in a pallid format. Vivid information is emotionally interesting, more thought provoking, and fosters a more elaborate encoding process (Nisbett \& Ross, 1980). For instance, research in marketing has found that pictures on the packaging of products increase shoppers' attention to a specific brand (Underwood, Klein, \& Burke, 2001). Recent research suggests that the reviewer’s photos facilitate systematic message processing (Lee \& Shin, 2014).

A review associated with an extreme rating can be perceived as untrustworthy (Filieri, 2016). However, customers' photos are also perceived as more credible than the professional photos posted by a company and are perceived as very helpful because they show what a product/service looks like before buying it (Filieri, 2016). This is even more important for experience services like hotels. Services are intangible (Zeithaml, Parasuraman, \& Berry, 1985), however pictures enable to visualize the service context, and help consumers to make inferences about its level of quality, before buying it. Visual depictions of services online can compensate for a lack of haptic information and increase confidence in product evaluations (Peck \& Childers, 2003; Papathanassis \& Knolle, 2011). Scholars suggest that photos are always more persuasive than words as readers could obtain more objective information from photos of a destination (Fang et al., 2016). Therefore, travelers' photos can justify an extreme opinion given by the reviewer of a hotel because they offer visual evidence and are perceived as objective and trustworthy (Filieri, 2016). Travelers' photos can increase the persuasiveness, hence the helpfulness of extreme reviews. Following these arguments we hypothesize: 
H3: Reviewer's photos of the hotel moderate the relationship between extreme ratings and helpfulness in such a way that extreme ratings will be voted as more helpful when associated with photos.

Reviewer's country of origin (local versus foreigner)

Previous studies on the factors affecting the helpfulness of a review have explored different factors related to the source of communication, such as some of the reviewer's identity information, reputation, expertise (Forman, Ghose \& Wiesenfeld, 2008; Racherla \& Friske, 2012; Park \& Nicolau, 2015; Liu \& Park, 2015). Research on online travel communities has found that residents are more influential in hotel, food and beverage recommendations (Yoo et al. 2007; Arsal et al., 2010). Accordingly, a local reviewer may be considered as a more expert source of information than a foreign reviewer due to his insider knowledge and information about the local context. In this study we define local sources those reviewers who are from the same country as the product/service being reviewed. In this study the sample of hotels is mainly composed of French hotels so French reviewers are considered as local reviewers in this study while reviewers of other nationalities are labelled as foreign reviewers. We contribute to this stream of research by conjecturing that the credibility of a local reviewer can also impact on the effect that extreme ratings have on review helpfulness. A local reviewer generally knows the place he/she lives in better than a foreign reviewer, thus he/she may be perceived as knowledgeable and expert of his/her country (Yoo et al. 2007; Arsal et al., 2010). Hence, we argue that when the rating is extreme the evaluations of a local reviewer will be more persuasive and thus considered as more helpful than extreme ratings provided by foreign reviewers. 
H4: The local origin of a reviewer moderates the relationship between extreme rating and review helpfulness in such a way that extreme rating will be voted as more helpful when produced by local reviewers.

\section{Product type: hotel size}

Previous studies have investigated the moderating role of product type and focused mainly on the distinction between experience versus search products (Mudambi \& Schuff, 2010; Racherla \& Friske, 2012; Chua \& Banerjee, 2016). In this study we consider the moderating role of the size of the experience product being reviewed: namely hotel size. The size of a hotel depends on the number of rooms available. Large hotels generally provide a consistent standard of service across different branches and destinations. Large hotels are often placed in strategic areas such as where the traffic of leisure and business tourists is intense, which means that they are more likely to be visited and reviewed by tourists. Moreover, because they have more resources to spend in marketing, they are more likely to have a website or social media platforms where they offer different types of information about the accommodation.

For the reasons mentioned above, consumers may be less likely to find extreme ratings as helpful for large hotels. Consumers may find more online reviews to assess large hotels than to assess small hotels. Moreover, large hotels are sometimes well-known. Hence, because consumers can find more and more easily information about large hotels and are also more likely to have knowledge in memory about them, they are less likely to find extreme ratings helpful for large hotels. The name of the large hotel will be immediately recalled at the time of the purchase decision, which means consumers do not have to engage in additional thinking or information processing to make a decision. Instead, consumers are less likely to have preliminary information and knowledge about small hotels. Small, family-run businesses like Bed \& Breakfast or small hotels often have fewer resources to spend, a lower 
number of services to offer, are more variable service (so less standardized) than large hotels. Small hotels are visited and consequently reviewed by a lower number of tourists compared to large hotels. Thus, when information is limited and there is no previous experience with a product/service, an extreme rating review stands out, is more attention-catching and potentially helpful to consumers.

Based on these considerations, and based on the fact that fewer reviews are available for smaller hotels and on the fact that the risk is greater in small hotels because of greater service variability, we suppose that extreme ratings are more helpful in case of smaller hotels. Therefore, we hypothesize that extreme ratings will be more helpful to consumers in the evaluation of small-sized hotels, and less helpful in the evaluation of large-sized hotels.

H5 Hotel size moderates the relationship between extreme ratings and OCR helpfulness, in such a way that extreme ratings will be voted as more helpful when the hotel is smaller.

Figure 1 provides a graphical representation of the relationships tested with the indication of the hypotheses they refer to.

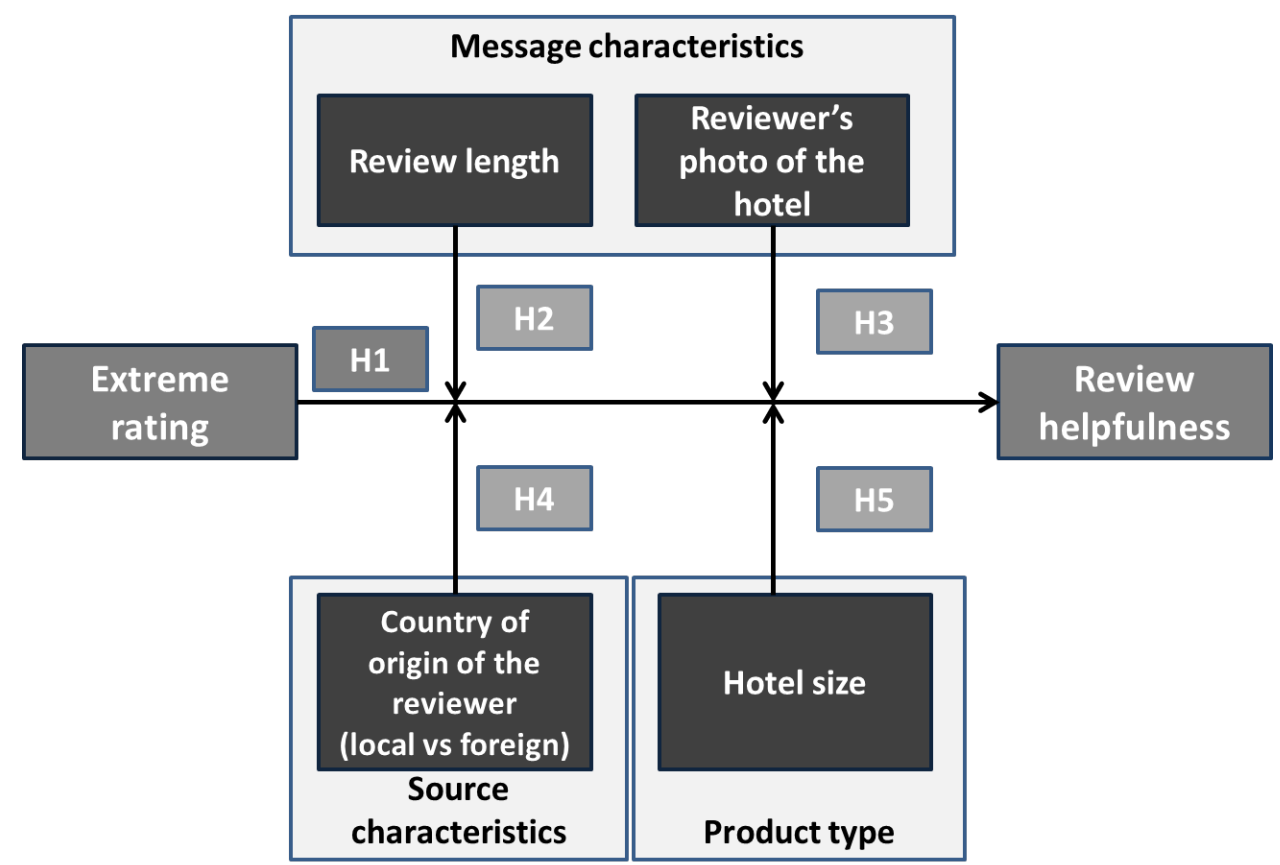


Figure 1 Theoretical framework and hypotheses

\section{Methodology}

This study focuses on online reviews for accommodation. From an economic point of view, hotels, with travel agents and airlines, contributed USD 2,364.8bn to global GDP in 2014. This contribution is expected to grow by 3.9\% per annum to USD 3,593.2bn by 2025 sizing the 3.3\% of global GDP (Roth \& Fishbin, 2015). Beyond this economic relevance, a theoretical gap exists and it relates to the multifaceted services proposed by hotels and the risky decision for the consumers about which hotel to book. On one hand, the potential hotel guests often have to assess several facets of the service before making a decision, such as the position and distance of the hotel from the city center or from the main destinations' attractions, the size of the room, the friendliness and helpfulness of hotel staff, the quality of breakfast, the safety and security of the hotel and its surroundings, and so on (e.g. Weaver \& Oh, 1993). On the other hand, booking a hotel room is a risky decision because of the high involvement, high physical risk, social visibility, limited experience, high cost, choice complexity, and purchase infrequency associated with it (Gretzel, Yoo, \& Purifoy, 2007; Reza et al., 2012). Hence, we expect that the multifaceted services of hotels and the risky decision for the consumers about which hotel to book imply that some specific factors may affect review helpfulness.

\section{Data collection}

This research collected data from TripAdvisor.com. We choose TripAdvisor.com because it is one of the most popular websites publishing online customer reviews. Particularly, 
TripAdvisor.com is widely used worldwide (Filieri, Alguezaui \& McLeay, 2015), facilitating replicability of our research and generalizability of our results.

Nonetheless, we limited our data collection to a single country, to reduce the variability of contextual variables. We decided to focus on French hotels because the French hotel industry has the highest number of beds in Europe (Eurostat, 2013) and because France is among the top five countries that will have the highest number of tourists booking on TripAdvisor.com in 2016 (TripBarometer, 2016). Finally, the hospitality industry has a considerable weight in the French economy.

French hotels to be selected had to satisfy two conditions: (1) the hotel is registered in IODSAltares, a database that contains the economic and financial data of French companies across all industries; (2) the hotel had been reviewed on TripAdvisor.com. We used random sampling to control the listing of hotels and to ensure that hotels were chosen independently from their characteristics. 90 hotels were selected and all the reviews of these hotels published on TripAdvisor.com (a total of 11,358 OCRs written between 2006 and 2015) were used in the data analysis. The data collection process involved a random selection of 90 French hotels from a population of 10,110 hotels and was computed by considering a confidence level of 95 percent and a confidence interval of 10 percent. We used STATA software version 11 to test the hypotheses formulated in this study.

\section{Data operationalization}

The dependent variable in our model was review helpfulness (Table 1), which was measured using the logarithmic form of the number of helpful votes received by an OCR (e.g. Liu \& Park, 2015) since it has a skewed graphical representation.

The independent variable in our model was the rating of the review, which represents the rating assigned to a review expressed on a scale from 1 (terrible) to 5 (excellent) (Park \& 
Nicolau, 2015). Extreme rating was measured by computing the squared value of the rating assigned to the OCR (Mudambi \& Schuff, 2010).

The moderating variable review length was measured counting the number of words included in an OCR (Liu \& Park, 2015). The moderating variable reviewer photos was measured as the logarithmic form of the number of photos posted on every OCR (Lin, Lu, \& Wu, 2012) since it has a skewed graphical representation. The moderating variable local source is a dummy variable which equals to 1 in case the reviewer is French, 0 otherwise (Forman, Ghose, \& Wiesenfeld, 2008). The final moderator hotel size is measured on the number of rooms, the standard measure of size used in the hotel industry (Simons \& Hinkin, 2001). Concerning the control variables, review readability represents the extent to which an individual comprehends the product information, which in turn leads to accepting the information (Zakaluk \& Samuels, 1988; Korfiatis et al., 2012). To understand the level of comprehension of an OCR, this research considers the Automated Readability Index (ARI), which represents the educational grade level required to understand the textual information analysed. The lower the grade, the more readable is the text (Korfiatis et al., 2012). For computing these indexes, the characters of each review (the number of letters, numbers and punctuation marks), the number of words and the sentences in each review were computed. We also included as control variable the quality of customer service, which is measured as the star-rating of a hotel. Hotels' official star-rating, a measure of vertical differentiation through customer service, was examined by looking at the number of stars (from 1 to 5) (Silva, 2015) assigned to the hotel by the agency for the tourism development in France.

Regarding reviewer personal information, online identity is salient when an individual is part of an online community. Information about the reviewer makes stronger and more effective the contributions. Therefore, identity disclosure reduces customers' uncertainty based on limited visibility on online environments (Tidwell \& Walther, 2002). This research measures 
the identity disclosure in terms of reviewer's city with the variable "Declared city" as a dummy variable equal to 1 in case the reviewer discloses information about his/her city, 0 otherwise.

We included the variable contributor level to control for the effect of reviewer experience (Filieri, 2016). We used TripAdvisor.com's badge system that shows the different levels of expertise of reviewers, which can range from "reviewer” to "top contributor”. Specifically, the considered variable was based on a scale from 1 to 5 . We also included the helpful votes obtained by the reviewer measured as the total number of reviews posted on TripAdvisor.com by the reviewer assessed as helpful by the other travellers (Ghose \& Ipeirotis, 2011), and the number of reviews on hotels measured as the total number of reviews on hotels posted on TripAdvisor.com by the reviewer (Weiss et al., 2008).

Table 1 Variable operationalization

\begin{tabular}{|c|c|c|c|}
\hline $\begin{array}{l}\text { Variable } \\
\text { type }\end{array}$ & Variable name & Operationalization & Reference \\
\hline $\begin{array}{l}\text { Dependent } \\
\text { variable }\end{array}$ & $\begin{array}{l}\text { Review } \\
\text { helpfulness }\end{array}$ & $\begin{array}{l}\text { The number of online users who voted the OCR with a } \\
\text { "like" to appreciate its helpfulness. }\end{array}$ & $\begin{array}{l}\text { Liu \& Park, } \\
2015 \\
\text { Lee et al., } \\
2017\end{array}$ \\
\hline \multirow[t]{5}{*}{$\begin{array}{l}\text { Independent } \\
\text { variables }\end{array}$} & Review rating & The rating of the OCRs expressed on a scale of 1-5. & $\begin{array}{l}\text { Park \& } \\
\text { Nicolau, } \\
2015\end{array}$ \\
\hline & Review length & The number of words of an online review. & $\begin{array}{l}\text { Liu \& Park, } \\
2015\end{array}$ \\
\hline & $\begin{array}{l}\text { Photos of the } \\
\text { hotel }\end{array}$ & The number of photos posted on every online review. & $\begin{array}{l}\text { Lin et al., } \\
2012\end{array}$ \\
\hline & Local source & $\begin{array}{l}\text { Dummy variable equal to } 1 \text { in case the reviewer is French, } \\
0 \text { otherwise. }\end{array}$ & $\begin{array}{l}\text { Forman, } \\
\text { Ghose, \& } \\
\text { Wiesenfeld, } \\
2008\end{array}$ \\
\hline & Firm size & The number of rooms in a hotel. & $\begin{array}{l}\text { Simons \& } \\
\text { Hinkin, } 2001\end{array}$ \\
\hline \multirow[t]{4}{*}{$\begin{array}{l}\text { Control } \\
\text { variables }\end{array}$} & $\begin{array}{l}\text { Review } \\
\text { readability }\end{array}$ & $\begin{array}{l}\text { ARI }=4.71 *(\text { Characters/words) }+0.5 * \\
\text { (words/Sentences) }-21.43\end{array}$ & $\begin{array}{l}\text { Korfiatis et } \\
\text { al., } 2012\end{array}$ \\
\hline & $\begin{array}{l}\text { Quality of } \\
\text { customer service }\end{array}$ & Star-rating: The number of stars of a hotel. & Silva, 2015 \\
\hline & $\begin{array}{l}\text { Identity } \\
\text { disclosure }\end{array}$ & $\begin{array}{l}\text { Declared city: Dummy variable equal to } 1 \text { in case the } \\
\text { reviewer declares its city, } 0 \text { otherwise. }\end{array}$ & $\begin{array}{l}\text { Forman, } \\
\text { Ghose, \& } \\
\text { Wiesenfeld, } \\
2008\end{array}$ \\
\hline & $\begin{array}{l}\text { Reviewer } \\
\text { expertise }\end{array}$ & $\begin{array}{l}\text { Contributor level: Level of the contributor from } 1 \\
\text { (reviewer) to } 5 \text { (top contributor). }\end{array}$ & Filieri, 2016 \\
\hline
\end{tabular}


Helpful votes obtained by the reviewer: The number of reviews posted on TripAdvisor.com by the reviewer assessed as helpful by the other travellers.

Number of reviews posted: The number of reviews on hotels posted on TripAdvisor.com by the reviewer.

Identification of A list of dummy variables for identified every hotel (one the hotel

Identification of A list of dummy variables for identified the year the the year
Ghose \& Ipeirotis, 2011 Weiss et al., 2008

n.a.

n.a.

\section{Data analysis}

Following previous research (Mudambi \& Schuff, 2010), we used the Tobit regression model due to the specific feature of helpful votes (dependent variable) and the censored nature of the sample to analyse data. This decision was taken for two reasons. First, the dependent variable is bounded in the extremes since travellers may either vote the review helpful or unhelpful. In this way they are extreme in their assessment. Second, Tobit regression analysis has the advantage of solving potential selection bias in this type of sample. TripAdvisor.com does not provide information about the number of people who read the online review while it only provides information about the total number of helpful votes a review has been awarded and their rating. If the probability of being part of a sample is correlated with an explanatory variable, the Ordinary Least Squares (OLS) and Generalized Least Squares (GLS) estimates can be biased (Kennedy, 1994). Therefore, this study performs Tobit regression analysis by analysing the data and measuring the fit with the likelihood ratio and pseudo R-square value (Long, 1997). The resulting tested equation, including all the effects tested isolated in different models, is the following one:

Review helpfulness $t_{t}=\beta_{1}$ Review rating ${ }_{t}+\beta_{2}$ Review rating ${ }_{t}^{2}+\beta_{3}$ Review length $t+$ $\beta_{4}$ Photos of the hotel $t_{t}+\beta_{5}$ Local source $_{t}+\beta_{6}$ Firm size $_{t}+\beta_{7}$ Review rating ${ }_{t} x$ Review length $_{t}+\beta_{8}$ Review rating $x$ Photos of the hotel $t_{t}+\beta_{9}$ Review rating ${ }_{t} \times$ Local source $_{t}+\beta_{10}$ Review rating ${ }_{t} x$ Firm size $_{t}+\beta_{11}$ Review rating ${ }_{t}^{2} x$ Review length ${ }_{t}+\beta_{12}$ Review rating $_{t}^{2} x$ Photos of the hotel $t_{t}+\beta_{13}$ Review rating ${ }_{t}^{2} \times$ Local source $_{t}+\beta_{14}$ Review rating $_{t}^{2} \times$ Firm size $_{t}$ $+\Sigma c v_{t}+\varepsilon_{t}$

where $\mathrm{Cv}_{\mathrm{t}}$ are the control variables at the time $\mathrm{t}$. 


\section{Results}

Table 2 shows the descriptive statistics. Specifically, the $46.90 \%$ of the reviews has at least one like, and the average rating of the consumer review is equal to 4.02 with an average review length of 100.75 words per review. In terms of the nationality of the reviewers, local people wrote $42.1 \%$ of all the reviews posted on TripAdvisor.com about the selected French hotels. These statistics indicate that it is more likely to find hotel reviews from foreign travellers rather than from French travellers. In the sample, the number of OCRs associated with customers' photos is lower than the number of reviews without a photo with an average of 0.251 . Furthermore, on average the hotel in the sample has 40.36 rooms. Considering instead the number of reviews that are written on average by every hotel in the period considered, the minimum value is equal to 11.754 and the maximum value to 71.213 .

Table 2 Descriptive statistics

\begin{tabular}{|c|c|c|c|c|c|}
\hline Variable & Minimum & Maximum & Mean & Median & $\begin{array}{l}\text { Standard } \\
\text { deviation }\end{array}$ \\
\hline \multicolumn{6}{|l|}{ Dependent variable } \\
\hline OCR helpfulness & 0 & 48 & 1.048 & 0 & 2.142 \\
\hline \multicolumn{6}{|c|}{ Independent variables } \\
\hline OCR rating & 1 & 5 & 4.02 & 4 & 1.053 \\
\hline Review length & 1 & 1,920 & 100.751 & 76 & 85.282 \\
\hline Photos of the hotel & 0 & 11 & 0.252 & 0 & 1.037 \\
\hline Local source & 0 & 1 & 0.341 & 0 & 0.474 \\
\hline Firm size & 6 & 189 & 40.362 & 36 & 29.949 \\
\hline \multicolumn{6}{|l|}{ Control variables } \\
\hline ARI & 1.11 & $3,214.841$ & 20.493 & 11.254 & 95.216 \\
\hline Star-rating & 1 & 5 & 3.263 & 3 & 0.935 \\
\hline Declared city & 0 & 1 & 0.842 & 1 & 0.464 \\
\hline Contributor level & 1 & 6 & 2.954 & 3 & 1.583 \\
\hline Helpful votes obtained by the reviewer & 0 & 1,482 & 22.486 & 8 & 44.723 \\
\hline $\begin{array}{l}\text { Number of reviews posted (by the } \\
\text { contributor) }\end{array}$ & 0 & 412 & 4.097 & 0 & 14.124 \\
\hline
\end{tabular}

Before running Tobit regression analysis we tested for multicollinearity, which can be an issue in regression analysis. All the variables have acceptable values of VIF and tolerance levels and therefore multicollinearity did not appear to be an issue (Table 3). 
Table 3 VIF and tolerance level values.

\begin{tabular}{lll}
\hline Variable & VIF & Tolerance \\
\hline Review rating & 1.012 & 0.988 \\
Review length & 1.112 & 0.899 \\
Reviewer photos & 1.017 & 0.983 \\
Local source & 1.016 & 0.984 \\
Firm size & 1.112 & 0.899 \\
\hline
\end{tabular}

Table 4 shows the results of regression analysis. In Model 1 we included all the variables without the interaction effects, while from Model 2 to Model 4 we tested the moderating effects by computing the interaction terms between review rating and the four moderating variables (review length, photos of the hotels, local source, and hotel size), and the interaction terms between the squared value of review rating and the three moderating variables mentioned above, by centring the values.

Model 1 provides support to hypotheses 1, while Model 2 provides support to H2 because review length significantly moderates the relationship between extreme ratings and review helpfulness, being extreme ratings perceived as more helpful when the review is long. H3 is supported because Model 3 shows that consumer pictures moderates significantly the relationship between extreme ratings and review helpfulness, making extreme rating more helpful when associated with consumer pictures. H4 is not supported (see Models 4) because we did not find any significant effect regarding the moderating role of local source. For hotel size (Hypothesis 5), we found a positive and significant relationship, instead of negative as supposed (see model 5). Finally, Model 6 confirms the findings by including all the variables in one model.

Table 4 Tobit regression models. Dependent variable: Review helpfulness.

\begin{tabular}{lcccccc}
\hline Model & M1 & M2 & M3 & M4 & M5 & M6 \\
\hline Control variables & & & & & & \\
\hline ARI & $0.001^{* * *}$ & $0.001^{* * *}$ & $0.001^{* * *}$ & $-0.001^{* * *}$ & $0.001^{* * *}$ & $-0.001^{* * *}$ \\
Star-rating & $(0.001)$ & $(0.002)$ & $(0.002)$ & $(0.002)$ & $(0.002)$ & $(0.002)$ \\
& $0.162^{* * *}$ & $0.162^{* * *}$ & $0.162^{* * *}$ & $0.162^{* * *}$ & $0.158^{* * *}$ & $0.159^{* * *}$ \\
Declared city & $(0.018)$ & $(0.018)$ & $(0.018)$ & $(0.018)$ & $(0.018)$ & $(0.018)$ \\
& -0.053 & -0.054 & $-0.055^{* * *}$ & -0.055 & -0.053 & -0.059 \\
& $(0.047)$ & $(0.047)$ & $(0.047)$ & $(0.047)$ & $(0.047)$ & $(0.047)$
\end{tabular}




\begin{tabular}{|c|c|c|c|c|c|c|}
\hline Contributor level & $\begin{array}{c}-0.057 * * * \\
(0.013)\end{array}$ & $\begin{array}{c}-0.058^{* * *} \\
(0.013)\end{array}$ & $\begin{array}{c}-0.057 * * * \\
(0.013)\end{array}$ & $\begin{array}{c}0.002 * * * \\
(0.001)\end{array}$ & $\begin{array}{c}-0.058^{* * *} \\
(0.013)\end{array}$ & $\begin{array}{c}-0.059 * * * \\
(0.013)\end{array}$ \\
\hline Helpful votes & $\begin{array}{c}0.002 * * * \\
(0.001)\end{array}$ & $\begin{array}{c}0.002 * * * \\
(0.001)\end{array}$ & $\begin{array}{c}0.002 * * * \\
(0.001)\end{array}$ & $\begin{array}{c}-0.002 * * * \\
(0.001)\end{array}$ & $\begin{array}{c}0.002 * * * \\
(0.001)\end{array}$ & $\begin{array}{c}0.002 * * * \\
(0.001)\end{array}$ \\
\hline Number of reviews on hotels & $\begin{array}{c}-0.002 \\
(0.001)\end{array}$ & $\begin{array}{l}-0.002 \\
(0.001)\end{array}$ & $\begin{array}{l}-0.002 \\
(0.001)\end{array}$ & $\begin{array}{l}-0.001 \\
(0.001)\end{array}$ & $\begin{array}{c}-0.002 \\
(0.001)\end{array}$ & $\begin{array}{l}-0.002 \\
(0.001)\end{array}$ \\
\hline \multicolumn{7}{|l|}{ First order effects } \\
\hline Review rating (OCRR) & $\begin{array}{c}-0.783^{* * *} \\
(0.084)\end{array}$ & $\begin{array}{c}-0.771^{* * *} \\
(0.085)\end{array}$ & $\begin{array}{c}-0.772^{* * *} \\
(0.084)\end{array}$ & $\begin{array}{c}-0.772^{* * *} \\
(0.083)\end{array}$ & $\begin{array}{c}-0.789 * * * \\
(0.084)\end{array}$ & $\begin{array}{c}-0.743^{* * *} \\
(0.086)\end{array}$ \\
\hline Review rating squared (OCRRsq) & $\begin{array}{c}0.584 * * * \\
(0.084)\end{array}$ & $\begin{array}{c}0.571^{* * *} \\
(0.085)\end{array}$ & $\begin{array}{c}0.574 * * * \\
(0.084)\end{array}$ & $\begin{array}{c}0.571^{* * *} \\
(0.084)\end{array}$ & $\begin{array}{c}0.592 * * * \\
(0.084)\end{array}$ & $\begin{array}{c}0.550 * * * \\
(0.086)\end{array}$ \\
\hline Review length (RL) & $\begin{array}{c}0.175^{* * *} \\
(0.016)\end{array}$ & $\begin{array}{c}0.178 * * * \\
(0.017)\end{array}$ & $\begin{array}{c}0.177 * * * \\
(0.016)\end{array}$ & $\begin{array}{c}0.174^{* * *} \\
(0.016)\end{array}$ & $\begin{array}{c}0.175^{* * *} \\
(0.016)\end{array}$ & $\begin{array}{c}0.173 * * * \\
(0.017)\end{array}$ \\
\hline Reviewer Photo (RP) & $\begin{array}{c}0.006 \\
(0.016)\end{array}$ & $\begin{array}{c}0.008 \\
(0.016)\end{array}$ & $\begin{array}{c}0.008 \\
(0.016)\end{array}$ & $\begin{array}{c}0.007 \\
(0.016)\end{array}$ & $\begin{array}{c}0.006 \\
(0.016)\end{array}$ & $\begin{array}{c}0.008 \\
(0.016)\end{array}$ \\
\hline Local source (LS) & $\begin{array}{l}-0.013 \\
(0.016)\end{array}$ & $\begin{array}{c}-0.011 \\
(0.016)\end{array}$ & $\begin{array}{c}-0.011 \\
(0.016)\end{array}$ & $\begin{array}{c}-0.011 \\
(0.016)\end{array}$ & $\begin{array}{l}-0.012 \\
(0.016)\end{array}$ & $\begin{array}{l}-0.011 \\
(0.016)\end{array}$ \\
\hline Hotel size (HS) & $\begin{array}{c}-0.115^{* * *} \\
(0.016)\end{array}$ & $\begin{array}{c}-0.116^{* * *} \\
(0.016)\end{array}$ & $\begin{array}{c}-0.115^{* * *} \\
(0.016)\end{array}$ & $\begin{array}{c}-0.117^{* * *} \\
(0.016)\end{array}$ & $\begin{array}{c}-0.096^{* * *} \\
(0.016)\end{array}$ & $\begin{array}{c}-0.098 * * * \\
(0.016)\end{array}$ \\
\hline \multicolumn{7}{|l|}{ Second order effects } \\
\hline RL x OCRR & & $\begin{array}{l}-0.124^{\dagger} \\
(0.074)\end{array}$ & & & & $\begin{array}{l}-0.137^{\dagger} \\
(0.075)\end{array}$ \\
\hline RP x OCRR & & & $\begin{array}{l}0.212^{*} \\
(0.088)\end{array}$ & & & $\begin{array}{l}0.220^{*} \\
(0.088)\end{array}$ \\
\hline LS x OCRR & & & & $\begin{array}{l}-0.145^{\dagger} \\
(0.082)\end{array}$ & & $\begin{array}{l}-0.161^{\dagger} \\
(0.083)\end{array}$ \\
\hline HS x OCRR & & & & & $\begin{array}{l}-0.161^{*} \\
(0.080)\end{array}$ & $\begin{array}{l}-0.134^{\dagger} \\
(0.080)\end{array}$ \\
\hline RL x OCRRsq & & $\begin{array}{l}0.142^{*} \\
(0.077)\end{array}$ & & & & $\begin{array}{l}0.141^{\dagger} \\
(0.078)\end{array}$ \\
\hline RP x OCRRsq & & & $\begin{array}{l}0.188^{*} \\
(0.086)\end{array}$ & & & $\begin{array}{l}0.199 * \\
(0.086)\end{array}$ \\
\hline LS x OCRRsq & & & & $\begin{array}{c}0.048 \\
(0.081)\end{array}$ & & $\begin{array}{c}0.062 \\
(0.083)\end{array}$ \\
\hline HS x OCRRsq & & & & & $\begin{array}{l}0.209^{*} \\
(0.081)\end{array}$ & $\begin{array}{l}0.189^{*} \\
(0.081)\end{array}$ \\
\hline Constant & $\begin{array}{c}4.230^{* * *} \\
(0.159)\end{array}$ & $\begin{array}{c}4.223^{* * *} \\
(0.159)\end{array}$ & $\begin{array}{c}4.229 * * * \\
(0.159)\end{array}$ & $\begin{array}{c}4.233^{* * *} \\
(0.159)\end{array}$ & $\begin{array}{c}4.231^{* * *} \\
(0.159)\end{array}$ & $\begin{array}{c}4.235^{* * *} \\
(0.159)\end{array}$ \\
\hline LR Chi-Squared & $1426.43 * * * *$ & $1432.95 * * *$ & $1430.28 * * *$ & $1465.99 * * *$ & $1440.39 * * *$ & $1491.07 * * *$ \\
\hline Pseudo R Squared & $3.97 \%$ & $3.98 \%$ & $3.98 \%$ & $4.08 \%$ & $4.00 \%$ & $4.15 \%$ \\
\hline
\end{tabular}

\section{Discussion}

If the direct relationship between extreme reviews and review helpfulness has been explored extensively in eWOM literature (Mudambi \& Schuff, 2010; Park \& Nicolau, 2015; Filieri, 2016; Hong et al., 2017), our contribution has been toward the still unexplored moderating effects in the relationship between extreme rating and review helpfulness. This study has used a dataset of 11,358 OCRs of 90 French hotels from TripAdvisor.com. The theoretical 
contribution lies in the fact that we have assessed the moderating influence of four different variables: two variables related to review message (i.e. review length, photos), one variable on the source of communication (i.e. geographical origin of the reviewer: foreign versus local), and one variable for the product type (i.e. large versus small hotel size). This study introduces a new stream of research into the factors moderating the influence of extreme ratings on review helpfulness.

Based on the findings, we can see that extreme ratings are perceived as helpful, which confirms previous findings in impression formation literature (e.g. Birnbaum, 1972; Hinkle, 1976; Wyer, 1974) and cue diagnosticity (Skowronski \& Carlston, 1989) as well as in eWOM (Park \& Nicolau, 2015; Liu \& Park, 2015; Fang et al., 2016). The findings confirm that extreme ratings are reference points to consumers to facilitate consumer's classification of services based on consumer's ratings. While the previous literature elucidated that extreme ratings are less helpful for experience goods purchased on Amazon (Mudambi \& Schuff, 2010), we showed that for hotels extreme ratings are more helpful than moderate ratings. Our result informs the theory, providing complementary results to the previous one analyzing restaurant services (Park \& Nicolau, 2015).

Concerning, the moderating effects, our findings show that review length positively moderates the relationship between extreme ratings and review helpfulness. We confirm the first hypothesis advancing that a short review with extreme evaluation (i.e. overly positive or negative rating) is less likely to be voted as helpful by consumers, than an extreme rating accompanied by a long review. This result can be explained by the fact that lengthy reviews may add more arguments that substantiate their extreme evaluation, so that consumers perceive the review as more rational and justifiable, which ultimately affect its persuasiveness. The length of an OCR can be particularly important to evaluate an extreme rating for a service like a hotel, which is multifaceted and involves a risky decision (e.g. Reza 
et al., 2012). Readers may find more credible a review posted by a reviewer who has spent some time in writing a long review than a review written by a reviewer who has written few words about a hotel (Pan \& Zhang, 2011; Filieri, 2016).

We found that the photos of a hotel provided by a reviewer moderates the impact of extreme ratings. Previous studies focus on the direct relationship between reviewer profile picture and review helpfulness (Forman, Ghose, \& Wiesenfeld, 2008; Racherla \& Friske, 2012; Hong et al., 2017) or suggested that reviewer photos can increase the trustworthiness of a consumer review (Filieri, 2016). In this study we found support for these findings as we have proved that the reviewer's photo contribute to increase the helpfulness of extreme ratings. Visual information stimulate cognitive elaboration, emotions (Nisbett \& Ross, 1980) and persuasion. We can conclude that an extreme rating accompanied by the reviewer's photo/s of the hotel can be perceived as more helpful than an extreme rating with no photos. It is possible to infer that the visual information adds credibility to the review (Filieri, 2016) by providing evidence that the writer has truly experienced the product/service and visually shows why his opinion is very negative or very positive (e.g. room cleanliness, breakfast quality, furniture quality, and so on). Our results strengthen the importance of visual information for intangible services (Zeithaml, Parasuraman, \& Berry, 1985). Photos enable to visualize the service context, and help consumers in making inferences about its level of quality before consuming it. Contrary to what expected, the local origin of the reviewer did not moderate the relationship between extreme rating and review helpfulness. Research on online travel communities found that residents are more influential in accommodation, food and beverage recommendations (Arsal et al., 2010). However, in our research the local origin of a reviewer did not moderate the relationship between extreme ratings and review helpfulness in the category of accommodation in the OCR setting. Accordingly, a local reviewer is not considered as a more accurate or experienced source of information than a foreign reviewer. Travelers do not 
believe that a local reviewer knows better about the offer and the quality of hotels available in his/her country of origin.

Contrarily to what hypothesized, we found that extreme ratings are perceived as more helpful for large hotels than for small hotels. This result can be probably due to the fact that travel consumers have generally higher expectations about the level of quality of large hotels than of small ones (Ariffin \& Maghzi, 2012). Although the size of a hotel is not synonymous of quality, tourism literature suggests that large hotels are typically more luxurious, have more features (Chung \& Kalnins, 2001), and are more innovative than small hotels (Orfila-Sintes et al., 2005). As such an extreme rating of a large hotel, especially if extremely negative, may create cognitive dissonance (Festinger, 1957). Cognitive dissonance is generated because consumers may hold positive expectations regarding service quality of large hotels and an extreme rating, especially if negative, can create inconsistency between what they expect and what other customers have experienced.

\section{Managerial implications}

Our results highlight some implications for practice. First of all, the managers of the social commerce and third-party websites publishing consumer reviews could instruct reviewers about the criteria that make an online review a potentially helpful one. Many websites increasingly request a minimum length for a review and ask reviewers to upload photos especially when the rating is extremely positive or negative. Moreover, reviewers could be better instructed about the rating system so that they are more aware of when they should attribute extreme ratings (positive or negative). Some rating systems clearly fail in providing information about the meaning associated to a 1 or a 5 star rating. 
In parallel, the managers of these organizations could better reward the reviewers who post extreme ratings complying with the criteria characterizing helpful reviews found in this study. These criteria could be communicated to the reviewers by, for example, adapting the review forms or via some mini and interactive tutorials.

This study also emphasizes the weight of an extreme rating in the traveler's decision-making for hotels. We found that extreme ratings (both extremely positive and negative), are helpful to travelers. We thus recommend managers to pay attention to what it is said on websites like TripAdvisor.com by their hosts because extreme ratings seem to be particularly helpful to travelers when they assess hotels. Accordingly, hotel managers should rapidly identify the most helpful reviews as soon as these are published. As soon as a helpful review is identified, the service provider should rapidly manage and eventually publicly respond to the review, without waiting for the other visitors of the website to assess the helpfulness of the review. Although we did not test this hypothesis, Kwok and Xie (2016) found that the response of a hotel manager moderates the influence of reviewer experience on review helpfulness. We believe that the prompt response by the service provider could attenuate the impact of an extremely negative rating and could enhance the impact of an extremely positive one.

\section{Limitations and future research}

Our study has some limitations. First, our results may not be generalizable to different countries or services. However, to generalize the results of this study, we suggest future research to compare reviews of hotels from different countries as well as services having different levels of complexity and risk (e.g. restaurants, travel tours). Moreover, our sample was based of hotels listed in TripAdvisor.com where OCRs are not posted only by verified purchasers like in Booking.com. Therefore perceived review credibility may be more important in this context than for other types of platforms (i.e. Booking.com) where the 
reviewer has effectively purchased the reviewed hotel. Accordingly, different platform contexts may provide different findings. Another limitation is that we could not control for the origin of the review reader when testing the effect of reviewer's origin in the relationship between extreme rating and review helpfulness.

Additionally, this study considered only some factors potentially moderating the relationship between extreme rating and review helpfulness. However, future studies could consider different variables as the features of a hotel and its classification, and reviewer's level of expertise (e.g. expertise).

Moreover, future studies could measure consumers’ perception of review helpfulness. For instance, services are intangible deeds and performances and their evaluation may depend on the interaction between a customer and a service provider, which can vary from situation to situation (Zeithaml et al., 1985) (e.g. from country to country). Thus, in this context homophily, namely the similarity between the source and the receiver of communication on the basis of similar ascriptive characteristics, such as gender, ethnicity, country of origin, appearance, and the like (McPherson, Smith-Lovin, \& Cook, 2001), may influence consumer's evaluation of review helpfulness as well as of service quality. For instance, it is possible that users perceive as more helpful those reviews that have been posted by users of their own nationality. Furthermore, consumers' evaluation of the helpfulness of a review can be influenced by their previous consumption experiences or by the reputation or the image of the brand (Jiang, Gretzel, \& Law, 2014). For instance, if a consumer has previous positive experience with a hotel brand or the brand is well known worldwide for providing excellent quality standards, his evaluation of the helpfulness of an extremely negative rating may be influenced by this experience or perception of the brand. Thus, future studies could consider adopting surveys or experiments to measure the influence of perceptual factors of review helpfulness such as homophily, perceived brand reputation, and previous experience with a 
hotel brand. Furthermore, we used the helpful votes as a proxy for helpful reviews following previous research (e.g. Mudambi \& Schuff, 2010). However, it is unlikely that all readers of an online review vote on its helpfulness, thus a potential selection problem may be present in these studies. Since hotel managers closely follow what it is said on TripAdvisor.com about their hotel, it is possible to expect that they may vote as helpful only the positive reviews left by their former customers. Thus, the number of helpful vote may be biased towards positive reviews. Finally, we suggest future research to combine qualitative and quantitative data to have a more holistic understanding of the findings.

\section{References}

Aiken, K. D., \& Boush, D. M. (2006). Trustmarks, objective-source ratings, and implied investments in advertising: investigating online trust and the context-specific nature of internet signals. Journal of the Academy of Marketing Science 34(3): 308-323.

Ariffin, A. A. M. \& Maghzi A. (2012). A preliminary study on customer expectations of hotel hospitality: Influences of personal and hotel factors. International Journal of Hospitality Management 31(1): 191-198.

Arsal, I., Woosnam, K. M., Baldwin, E. D., \& Backman, S. J. (2010). Residents as travel destination information providers: An online community perspective. Journal of Travel Research 49(4): 400-413.

Ayeh, J. K., Au, N., \& Law, R. (2013). Predicting the intention to use consumer-generated media for travel planning. Tourism Management 35(April 2013): 132-143.

Berger, C. R., \& Calabrese, R. J. (1975). Some explorations in initial interaction and beyond: toward a developmental theory of interpersonal communication. Human Communication Research 1(2): 99-112.

Birnbaum, M. H. (1972). Morality judgments: Tests of an averaging model. Journal of Experimental Psychology, 93(1): 35.

Cao, Q., Duan, W., Gan, Q. (2011) Exploring determinants of voting for the "helpfulness" of online user reviews: A text mining approach. Decision Support Systems, 50(2): 511-521.

Chevalier, J., \& Mayzlin, D. (2006). The effect of word of mouth on sales: Online book reviews. Journal of Marketing Research 43(August): 345-54.

Chua, A. Y., \& Banerjee, S. (2016). Helpfulness of user-generated reviews as a function of review sentiment, product type and information quality. Computers in Human Behavior, 54(January 2016): 547-554.

Cox, C., Burgess, S., Sellitto, C., \& Buultjens, J. (2009). The role of user-generated content in tourists' travel planning behavior. Journal of Hospitality Marketing \& Management, 18(8): 743-764. 
De Ascaniis, S., \& Morasso, S.G. (2011). When tourists give their reasons on the web: The argumentative significance of tourism related UGC. In: Law R., Fuchs M., Ricci F. (eds.) Information and Communication Technologies in Tourism 2011. Springer, Vienna.

Eurostat (2013) Tourism accommodation establishment, http://ec.europa.eu/eurostat/statistics-explained/index.php/Glossary:Tourist_accommodation_ establishment.

Fang, B., Ye, Q., Kucukusta, D., \& Law, R. (2016). Analysis of the perceived value of online tourism reviews: influence of readability and reviewer characteristics. Tourism Management 52: 498-506.

Festinger L (1957). A theory of cognitive dissonance. Evanston. IL: Row, Peterson 1.

Filieri, R., \& McLeay, F. (2014). E-WOM and Accommodation: An Analysis of the Factors that Influence Travelers' Adoption of Information from Online Reviews. Journal of Travel Research 53(1): 44-57.

Filieri, R., Alguezaui, S., \& McLeay, F. (2015). Why do travelers trust TripAdvisor.com? Antecedents of trust towards consumer-generated media and its influence on recommendation adoption and word of mouth. Tourism Management 51(December 2015): 174-185.

Filieri, R. (2015). What makes online reviews helpful? A diagnosticity-adoption framework to explain informational and normative influences in e-WOM. Journal of Business Research, 68(6): 1261-1270.

Filieri, R. (2016). What makes an online consumer review trustworthy? Annals of Tourism Research 58(May 2016): 46-64.

Forman, C., Ghose, A., \& Wiesenfeld, B. (2008). Examining the relationship between reviews and sales: The role of reviewer identity disclosure in electronic markets. Information Systems Research 19(3): 291-313.

Ghose, A., \& Ipeirotis, P. G. (2011). Estimating the helpfulness and economic impact of product reviews: Mining text and reviewer characteristics. IEEE Transactions on Knowledge and Data Engineering 23(10): 1498-1512.

Gretzel, U., Yoo, K.-H., \& Purifoy, M. (2007) Trip Advisor online travel review study: The role and impacts of online travel review for trip planning. College Station, TX: Laboratory for Intelligent Systems in Tourism.

Herr, P. M., Kardes, F. R., \& Kim, J. (1991). Effects of word-of-mouth and product-attribute information on persuasion: An accessibility-diagnosticity perspective. Journal of Consumer Research 17(4): 454-462.

Hong, H., Xu, D. Wang, A., \& Fan, W. (2017). Understanding the determinants of online review helpfulness: A meta-analytical investigation, Decision Support Systems 102(October 2017): 1-11.

Huang, A. H., Chen, K., Yen, D. C., \& Tran, T. P. (2015). A study of factors that contribute to online review helpfulness. Computers in Human Behavior 48: 17-27.

Kennedy, P. (1994). A Guide to Econometrics (3rd ed.), Oxford, England: Blackwell Publishers.

Karimi, S., \& Wang, F. (2017). Online review helpfulness: Impact of reviewer profile image. Decision Support Systems, 96: 39-48. 
Korfiatis, N., García-Bariocanal, E., \& Sánchez-Alonso, S. (2012). Evaluating content quality and helpfulness of online product reviews: The interplay of review helpfulness vs. review content. Electronic Commerce Research and Applications 11(3): 205-217.

Kwok, L., \& Xie, K.L., (2016). Factors contributing to the helpfulness of online hotel reviews: Does manager response play a role? International Journal of Contemporary Hospitality Management 28(10): 2156-2177.

Jiang, Z.H. \& Benbasat, I. (2007). Investigating the influence of the functional mechanisms of online product presentations. Information Systems Research 18(4): 221-244.

Jiang, J., Gretzel, U. \& Law, R. (2014). Influence of Star Rating and Ownership Structure on Brand Image of Mainland China Hotels. Journal of China Tourism Research, 10(1): 69-94,

Lee, M., Jeong, M., \& Lee, J. (2017). Roles of negative emotions in customers’ perceived helpfulness of hotel reviews on a user-generated review website: a text mining approach. International Journal of Contemporary Hospitality Management, 29(2): 762-783.

Lee, E. J., \& Shin, S. Y. (2014). When do consumers buy online product reviews? Effects of review quality, product type, and reviewer's photo. Computers in Human Behavior 31: 356366.

Lin, T. M., Lu, K. Y., \& Wu, J. J. (2012). The effects of visual information in eWOM communication. Journal of Research in Interactive Marketing 6(1): 7-26.

Litvin, S. W., Goldsmith, R. E., \& Pan, B. (2008). Electronic word-of-mouth in hospitality and tourism management. Tourism Management 29(3): 458-468.

Liu, Z., \& Park, S. (2015). What makes a useful online review? Implication for travel product websites. Tourism Management 47: 140-151.

Long, J. S. (1997). Regression Models for Categorical and Limited Dependent Variables, Thousand Oaks, CA: Sage Publications.

McPherson, M., Smith-Lovin, L., \& Cook, J. M. (2001). Birds of a feather: Homophily in social networks. Annual Review of Sociology 27: 415-444.

Mintel (2015). Mintel American Lifestyles 2015: The Connected Consumer - Seeking Validation from the Online Collective - US April 2015.

Mudambi, S. M. \& Schuff, D. (2010). What Makes a Helpful Online Review? A Study of Customer Reviews on Amazon.com. MIS Quarterly 34(1): 185-200.

Neirotti, P., Raguseo, E., \& Paolucci, E. (2016). Are customers' reviews creating value in the hospitality industry? Exploring the moderating effects of market positioning. International Journal of Information Management 36(6): 1133-1143.

Nisbett, R., \& Ross, L. (1980). Human inference: Strategies and shortcomings of social judgment. Englewood Cliffs, NJ: Prentice-Hall.

Pan, Y., \& Zhang, J. Q. (2011). Born unequal: A study of the helpfulness of user-generated product reviews. Journal of Retailing 87(4): 598-612.

Papathanassis, A., \& Knolle, F. (2011). Exploring the adoption and processing of online holiday reviews: A grounded theory approach. Tourism Management 32(2): 215-224. 
Park, D.-H., Lee, J., \& Han, I. (2007). The effect of online consumer reviews on consumer purchasing intention: The moderating role of involvement. International Journal of Electronic Commerce 11(4): 125-148.

Park, D.-H., \& Lee, J. (2008). E-WOM overload and its effect on consumer behavioural intention depending on consumer involvement. Electronic Commerce Research \& Applications 7(4): 386-398.

Park, S., \& Nicolau, J. L. (2015). Asymmetric effects of online consumer reviews. Annals of Tourism Research 50: 67-83.

Peck, J., \& Childers, T.L. (2003). To Have and To Hold: The Influence of Haptic Information on Product Judgments. Journal of Marketing 67(2): 35-48.

Phillips, P., Zigan, K., Silva, M. M. S., \& Schegg, R. (2015). The interactive effects of online reviews on the determinants of Swiss hotel performance: A neural network analysis. Tourism Management 50: 130-141.

Racherla, P., \& Friske, W. (2012). Perceived 'Usefulness’ of Online Consumer Reviews: An Exploratory Investigation across Three Services Categories. Electronic Commerce Research and Applications 11(6): 548-59.

Raguseo, E. \& Vitari, C. (2016). The Effect of Brand on the Impact of e-WOM on Hotels' Financial Performance. International Journal of Electronic Commerce 21(2): 1-21.

Reza, J., N. Samiei, B., Dini, \& Yaghoubi, P. (2012). Examining the structural relationships of electronic word of mouth, destination image, tourist attitude toward destination and travel intention: an integrated approach. Journal of Destination Marketing \& Management 1(1-2): 134-143.

Roth, H. \& Fishbin, M. (2015) Global hospitality insights. Top thoughts for 2015. EY, Building a better working world, 1-36.

Silva R (2015). Multimarket contact, differentiation, and prices of chain hotels. Tourism Management 48: 305-315.

Skowronski, J. J., \& Carlston, D. E. (1989). Negativity and extremity biases in impression formation: A review of explanations. Psychological bulletin, 105(1): 131.

Sparks, B. A., Perkins, H. E., \& Buckley, R. (2013). Online travel reviews as persuasive communication: The effects of content type, source, and certification logos on consumer behavior. Tourism Management 39: 1-9.

Sparks, B. A., So, K. K. F., \& Bradley, G. L. (2016). Responding to negative online reviews: The effects of hotel responses on customer inferences of trust and concern. Tourism Management 53: 74-85.

Tidwell, L.C. \& Walther, J.B. (2002). Computer-mediated communication effects on disclosure, impressions, and interpersonal evaluations: Getting to know one another a bit at a time. Human communication research 28(3): 317-348.

TripBarometer (2016). 6 key travel trends for 2016, https://www.TripAdvisor.com.com/TripAdvisor.comInsights/n2670/6-key-travel-trends2016.

Underwood, R. L., Klein, N. M. \& Burke, R. R. (2001). Packaging communication: attentional effects of product imagery. Journal of Product \& Brand Management 10(7): 403422. 
Viglia, G., Furlan, R., \& Ladrón-de-Guevara, A. (2014). Please, talk about it! When hotel popularity boosts preferences. International Journal of Hospitality Management 42: 155-164.

Weaver, P.A., Oh, H.C. (1993). Do American business travellers have different hotel service requirements? International Journal of Contemporary Hospitality Management 5(3): 16-21.

Wyer, R. S. (1974). Cognitive organization and change: An information-processing approach. Potomac, Md.: Erlbaum, 1974.

Wyer, R. S., \& Hinkle, R. L. (1976). Informational factors underlying inferences about hypothetical persons. Journal of Personality and Social Psychology, 34(3), 481-495.

Ye, Q., Law, R., Gu, B., \& Chen, W. (2011). The influence of user-generated content on traveler behavior: An empirical investigation on the effects of e-word-of-mouth to hotel online bookings. Computers in Human Behavior 27(2): 634-639.

Yin, D., Bond, S. \& Zhang, H. (2014). Anxious or Angry? Effects of Discrete Emotions on the Perceived Helpfulness of Online Reviews. MIS Quarterly 38(2) : 539-60.

Yoo, K.-H., Lee, K. S. \& Gretzel, U. (2007). The Role of Source Characteristics in eWOM: What Makes Online Travel Reviewers Credible and Likeable?, ENTER 2007 International Conference on Information and Communication Technologies in Tourism, Ljubljana, Slovenia.

Yoo, K.-H., \& Gretzel, U. (2009). Comparison of deceptive and truthful travel reviews. In W. Höpken, U. Gretzel, \& R. Law (Eds.), Information and communication technologies in tourism 2009 (pp. 37-48). Vienna, Austria: Springer.

Zakaluk, B. L., \& Samuels, S. J. (1988). Readability: Its Past, Present, and Future. International Reading Association, 800 Barksdale Rd., PO Box 8139, Newark, DE 197148139 (Book No. 795).

Zeithaml, V., Parasuraman, A., \& Berry, L.L. (1985). Problems and Strategies in Services Marketing. Journal of Marketing 49(2): 33-46.

Zhang, L., Wu, L. L., \& Mattila, A. S. (2016). Online Reviews: The Role of Information Load and Peripheral Factors. Journal of Travel Research 55(3): 299-310. 